\title{
Preparation of Poly[(ether)-(ether ether ketone)] Dendrimers by the Convergent Method
}

\author{
Atsushi MoRIKAWA ${ }^{\dagger}$ and Katsumichi ONO \\ Department of Materials Science, Faculty of Engineering, Ibaraki University, \\ 4-12-1 Nakanarusawa, Hitachi-shi Ibaraki 316-8511, Japan
}

(Received August 17, 1999)

\begin{abstract}
New highly branched poly[(ether)-(ether ether ketone)] dendrimers were synthesized by the convergent approach using two building blocks, 3, 5-dihydroxybenzyl alcohol, 1, and 3, 5-dihydroxy-4'-(4-fluorobenzoyl)diphenylether, 2, alternatively. The reaction of $p$-fluorobenzonitrile and 1 gave 3,5-di(4-cyanophenoxy)benzylalcohol (the first generation dendron, G 1-OH). After G 1-OH was converted to 3, 5-di(4-cyanophenoxy)benzylbromide (G 1-Br), the resultant benzylic bromide functionality was allowed to react with 2 to yield the second-generation dendron $(\mathbf{G ~ 2 - F})$. The third-generation dendron $(\mathbf{G ~ 3 - O H})$ was obtained by the reaction of $\mathbf{G} 2-\mathbf{F}$ and $\mathbf{1}$, and the fourth-generation dendron $(\mathbf{G}$ 4-F) was obtained by reaction of G 3-Br derived from G 3-OH, with 2 . Finally, dendrimers, Den-(G 2) ${ }_{3}$ and Den-(G 4) ${ }_{3}$ were synthesized by reaction of $\mathbf{G} \mathbf{2}-\mathbf{F}$ and $\mathbf{G} 4-\mathbf{F}$ with trifunctional core, respectively. Analysis was made of these structurally unambiguous dendrons and dendrimers by gel permeation chromatography (GPC) and matrix-assisted laser desorption ionization time of flight (MALDI-TOF) mass spectroscopy. ${ }^{1} \mathrm{H}$ and ${ }^{13} \mathrm{C}$ NMR spectra were consistent with the structures of these dendrons and dendrimers.
\end{abstract}

KEY WORDS Poly[(ether)-(ether ether ketone)] Dendrimers / 3, 5-Dihydroxybenzyl alcohol / 3,5-

Dihydroxy-4'-(4-fluorobenzoyl)diphenylether / Two Building Blocks / Alternatively /

Dendrimers ${ }^{1-4}$ are molecules with highly branched structures, and have been prepared by a divergent ${ }^{5-8}$ or a convergent method, ${ }^{9-11}$ which consists of repeating stepwise reactions. In the divergent method, the preparation starts from a core molecule, which possesses two or more reactive groups. A building block contains one functional group to connect with reactive groups of the core and two or more protected reactive group, which are the same as those of the core. In the convergent method, a compound possessing only one reactive group is used as the starting molecule. The building block contains two or more connecting points and only one protected reactive group, and the preparation starts to the inside direction from peripheral molecule. In both cases, after the reactive points on the starting molecule and the building block are connected, the protected reactive points are released. Connection of building blocks followed by deprotection are repeated until the molecules have grown to the desired size. ${ }^{12,13}$

Recently, we reported the preparation of poly(ether ether ketone) dendrimers by the divergent method, using 3,5-dimethoxy-4' -(4-fluorobenzoyl)diphenylether, 3 (eq 1), as the building block. ${ }^{14}$ The methoxy groups were the protective form for hydroxy groups, and the dendrimers were grown by a reaction between the hydroxy groups and aromatic fluorides activated by carbonyl

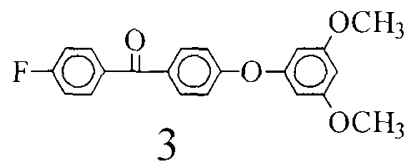

groups in the para position. To prepare dendritic molecules using this building block by the convergent method, the methoxy groups and 4-fluorobenzoyl group should be converted to reactive hydroxy groups and a protective form, respectively. However, there were no proper groups in the protective form for 4-fluorobenzoyl group.

Consequently, in this study, 3, 5-dihydroxybenzyl alcohol, 1, used as the building block in the synthesis of polyether dendrimers, ${ }^{10}$ and 3,5-dihydroxy-4'-(4fluorobenzoyl)diphenylether, $\mathbf{2}$, derived from $\mathbf{3}$, were used as building blocks alternatively without protecting 4-fluorobenzoyl group. Generally, the shape of dendrimers, prepared from only one building block, are thought to be flexible and expanded structures in low generation and be more globular with increasing generation. ${ }^{15}$ However, in the case of the present dendrimers, such the transition to the globular structure is expected to be difficult due to the alternation of the lengths between the branching points. By such a method, wherein some different building blocks are used, arboral, ${ }^{16}$ poly(etherurethane), ${ }^{17}$ poly(amine-ester) ${ }^{18}$ poly(arylacetylene ${ }^{19}$, poly(ester-arylacetylene), ${ }^{20}$ poly(phenylenevinylene) ${ }^{21}$ poly(ether ketone), ${ }^{22}$ and cyclodextrin-modified dendrimer, ${ }^{23-24}$ have been synthesized.

In our previous convergent synthesis of poly(ether ketone), ${ }^{22}$ it was thought to be impossible to introduce functional groups into the periphery because highly reactive aluminum chloride was used in the conversion of the protected methoxy group to the reactive hydroxy group. However, as the dendrimers could be prepared without such conversion in this convergent synthesis, cyano groups, which can be converted to other functional groups such as carboxylic acid and amine, could be introduced at the periphery using 4-fluorobenzonitrile as the starting molecule. Such a dendrimers, with hydrophilic outer surfaces, are expected to be applied as micelles. ${ }^{25}$

\footnotetext{
${ }^{\dagger}$ To whom correspondence should be addressed.
} 

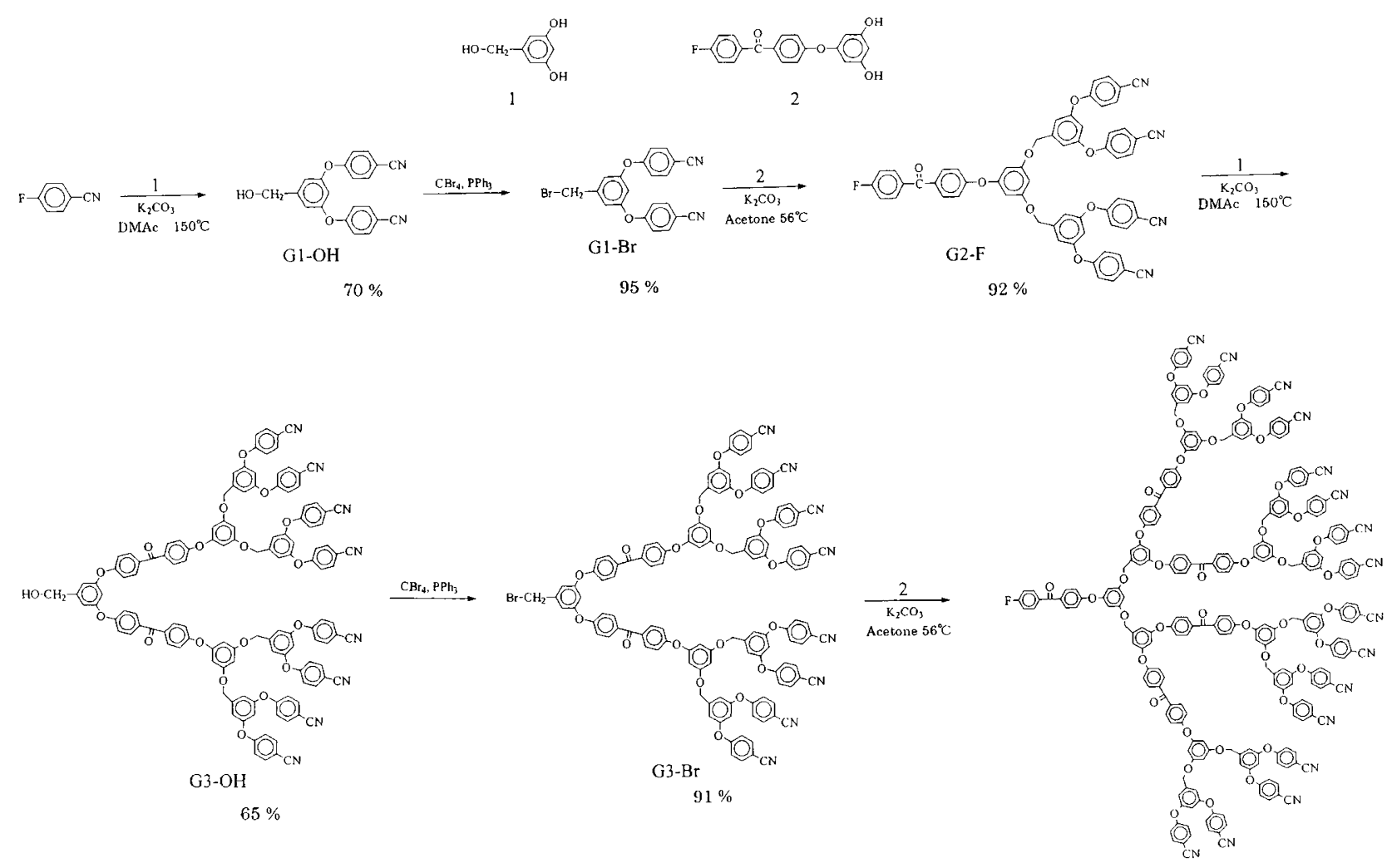

G4-F

Scheme 1.

\section{RESULTS AND DISCUSSION}

As two the building blocks were used in the present synthesis of the dendritic molecules, the covalent bonds for extension to dendrimers were two ethers; aromatic benzyl ether formed by the reaction between phenolic groups and benzyl bromide derivative, and aromatic aromatic ether formed by reaction between phenolic group and aryl fluoride activated by electron withdrawing group. As the former reaction proceeded at lower temperatures than the later, 4-fluorobenzoyl group of $\mathbf{2}$ was expected to be inert under the conditions of the former reaction.

A general synthetic procedure for the poly[(ether)(ether ether ketone)] dendrimers is shown in Scheme 1. First, reaction of $p$-fluorobenzonitrile and 1 gave 3, 5-di(4-cyanophenoxy)benzylalcohol (the first generation dendron, G1-OH). After G1-OH was converted to 3, 5-di(4cyanophenoxy)benzylbromide $(\mathbf{G 1}-\mathbf{B r})$, the resultant benzylic bromide functionality was allowed to react with 2 to yield the second-generation dendron (G2-F). Further reaction of $\mathbf{G 2}-\mathbf{F}$ with $\mathbf{1}$ yielded the thirdgeneration dendron (G3-OH), and the fourth-generation dendron $(\mathbf{G 4}-\mathbf{F})$ was obtained by reaction of $\mathbf{G 3}-\mathbf{B r}$ derived from G3-OH, with 2 . The reaction for the preparation of $\mathbf{G}-\mathbf{O H}$ proceeded at $150^{\circ} \mathrm{C}$ using a mixture of $N$, $N$-dimethylacetamide and toluene as solvent, and that of G-F proceeded at the reflux temperature $\left(56^{\circ} \mathrm{C}\right)$ using acetone as a solvent. The method for the conversion of $\mathbf{G}$ - $\mathbf{O H}$ to $\mathbf{G}-\mathbf{B r}$ was the same as that reported by Hawker et al. for the preparation of polyether dendrimers. ${ }^{10}$ These dendrons, G1-OH, G1-Br, G2-F, G3-OH, G3$\mathbf{B r}$, and $\mathbf{G 4}-\mathbf{F}$, were colorless powders purified by silica gel column chromatography with final isolated yields of $70,95,92,65,91$, and $88 \%$, respectively. The yield of G3 -OH was slightly lower due to the presence of small amounts of impurities as shown in GPC curves (Figure 1). In the MALDI-TOF mass spectra (Figure 2) of the crude G3-OH, $\mathrm{m} / \mathrm{z}$ of the signal for the lower molecular weight impurity corresponded to the molecular weight of G2-F and that for the higher molecular weight impurity corresponded to the molecular weight of the compound $\mathbf{5}$, which was formed by reaction between benzylic alcohol group of G3-OH and G2-F (Scheme 2). The reaction between 1 and $\mathbf{G 2}-\mathbf{F}$ at higher than $150^{\circ} \mathrm{C}$ resulted in higher ratio of $\mathbf{5}$ to $\mathbf{G 3}-\mathbf{O H}$ and lower yield of G3-OH. The reaction at $155^{\circ} \mathrm{C}$ gave $\mathbf{G 3}-\mathbf{O H}$ in only $38 \%$. Finally, dendrimers, Den-(G2) ${ }_{3}$ and Den-(G4) ${ }_{3}$ were synthesized by the reaction of $\mathbf{G 2}-\mathbf{F}$ and $\mathbf{G 4}-\mathbf{F}$ with trifunctional core 4, respectively (Scheme 3 ).

The formation and purity of these dendrimers were confirmed by gel permeation chromatography (GPC) (Figure 1) and MALDI-TOF-MS (Figure 2). In the MALDI-TOF mass spectra of the purified dendritic molecules, molecular ion peaks occurred at $\mathrm{m} / \mathrm{z}$ which agreed very closely with calculated values, and all spectra confirmed that the products were of very high purity and monodispersed.

Figure 3 shows the ${ }^{1} \mathrm{H}$ NMR spectra of $\mathbf{G 4}-\mathbf{F}$ and Den-(G4) $)_{3}$. The resonance of G4-F, could be classified as that of the methylene protons $(4.9-5.1 \mathrm{ppm})$, protons 
on 1,3,5-trisubstituted aromatic rings with three oxygen atoms, ascribed to $2(6.2-6.5 \mathrm{ppm})$, protons on the 1 , 3,5 -trisubstituted aromatic rings with two oxygen atoms and methylene group, ascribed to $1(6.6-7.0 \mathrm{ppm})$, protons on the meta-position of the carbonyl and cyano groups ( $7.0-7.2 \mathrm{ppm})$, and protons on the ortho-position of the carbonyl and cyano groups $(7.5-7.9 \mathrm{ppm})$. In the ${ }^{1} \mathrm{H}$ NMR spectrum of Den-(G4) 3 ), the resonance of the protons on the fluorine substituted aromatic ring (7.13 and $7.76 \mathrm{ppm}, \triangle$ ) of $\mathbf{G 4}-\mathbf{F}$ shifted, while that of the aromatic protons ascribed to $4(7.17,7.67,7.71$, and 7.88 ppm, O) appeared. The obtained ratios of these protons agreed with calculated values.

In the ${ }^{13} \mathrm{C}$ NMR spectra of these dendritic molecules, three methylene resonances ; $-\mathrm{CH}_{2}-\mathrm{OH}(64-65 \mathrm{ppm})$, $-\mathrm{CH}_{2}-\mathrm{Br}(31-32 \mathrm{ppm})$, and $-\mathrm{CH}_{2}-\mathrm{O}-\mathrm{Ar}(68-70 \mathrm{ppm})$, were easily distinguishable. However, aromatic reso-

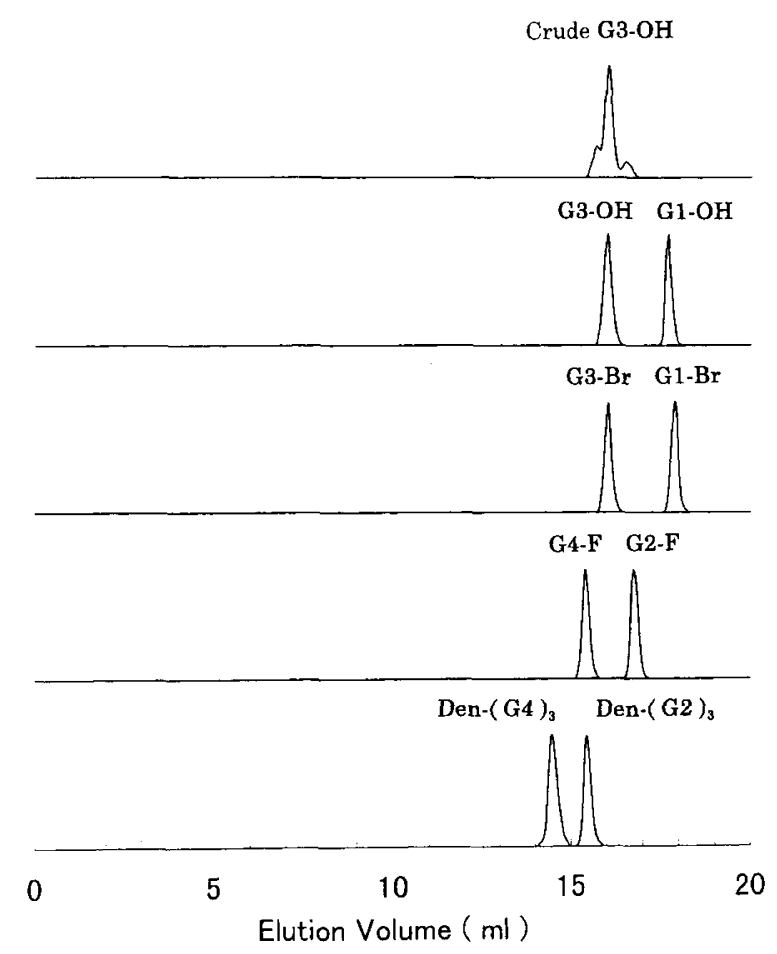

Figure 1. GPC curves of poly[(ether)-(ether ether ketone)] dendrimers. nance was complicated due to the presence of many signals. Thus, only the region $96-116 \mathrm{ppm}$ of these dendritic molecules, the most distinctive, are shown in Figure 4. Resonance for the carbons bonded to hydrogen atoms on the 1, 3, 5-trisubstituted aromatic rings was seen in this region; the resonance attributed to the trisubstituted aromatic rings with three oxygen atoms, at 98 $100 \mathrm{ppm}$ ( $\mathrm{a}$ and $\mathrm{b}$ ), and to the trisubstituted aromatic rings with two oxygen atoms and methylene group, at $110-116 \mathrm{ppm}$ ( $\mathrm{c}$ and $\mathrm{d}$ ). The resonance was clearly separated, and chemical structures of these dendritic mole-

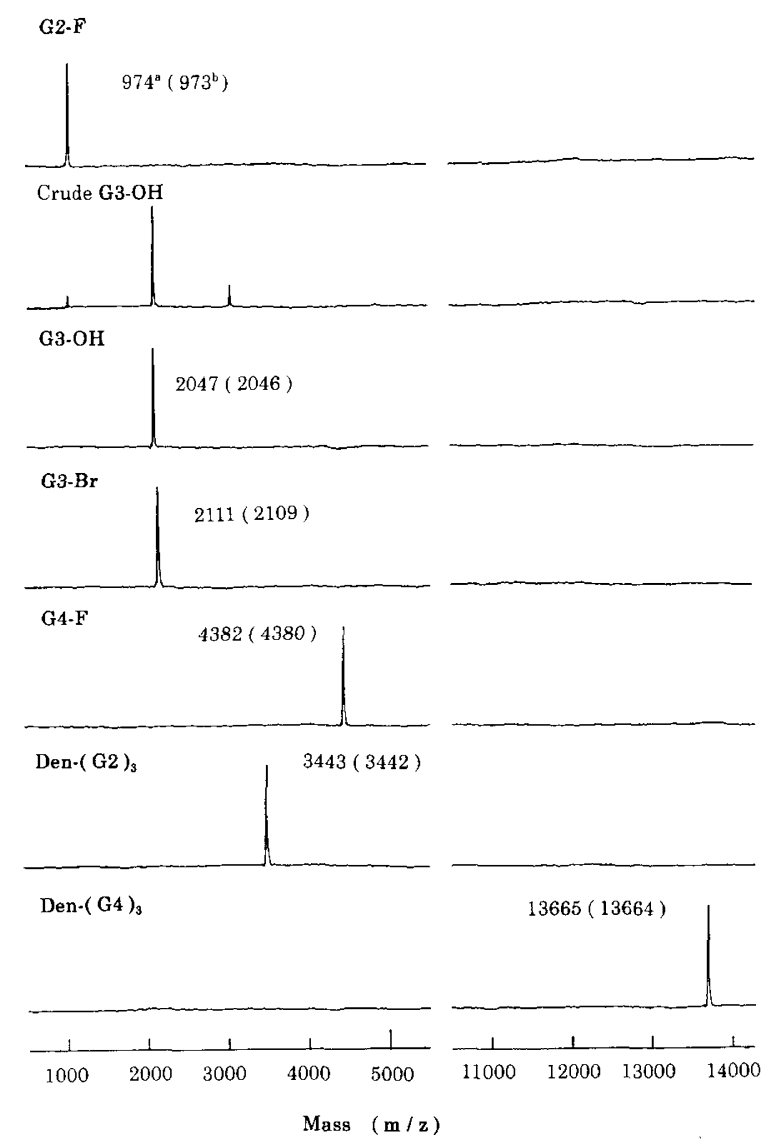

Figure 2. MALDI-TOF mass spectra and the molecular mass data of poly[(ether)-(ether ether ketone)] dendrimers. ${ }^{a}$ Measured mass. ${ }^{b}$ Calculated mass.

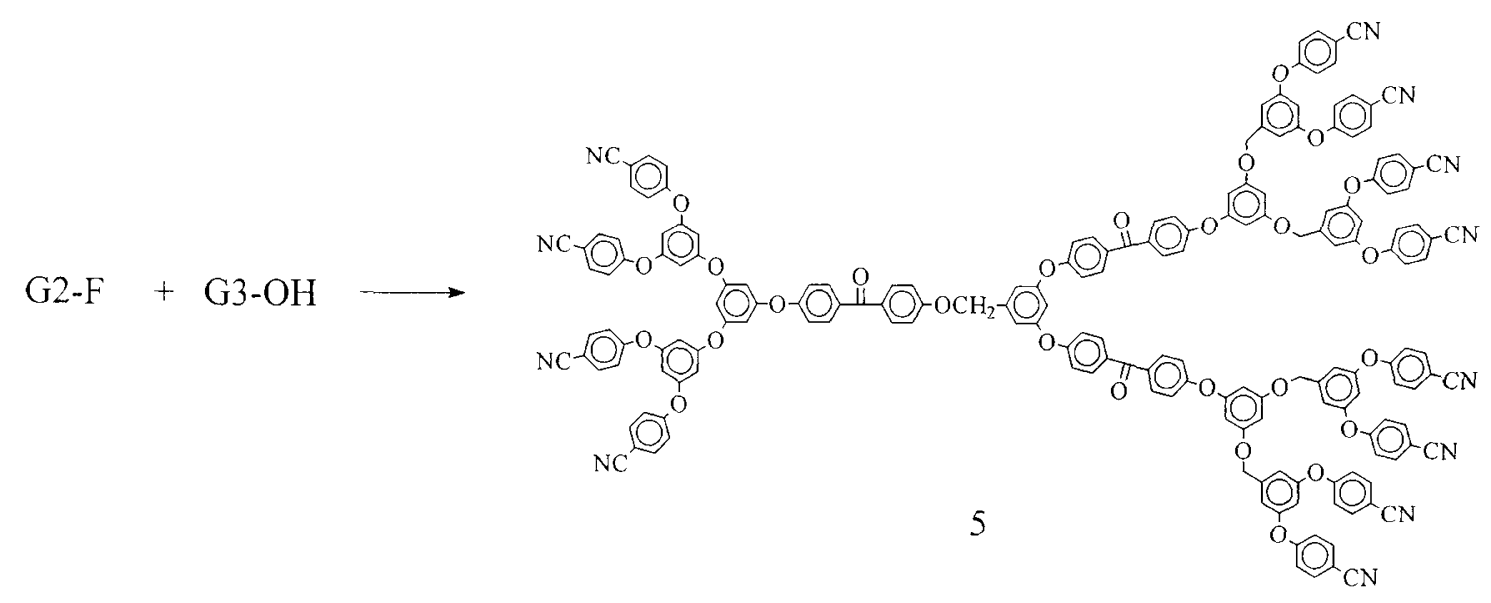

Scheme 2. 


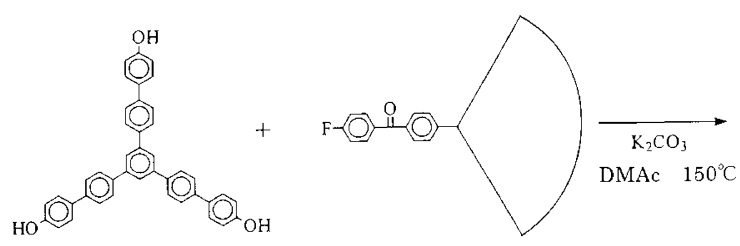

4

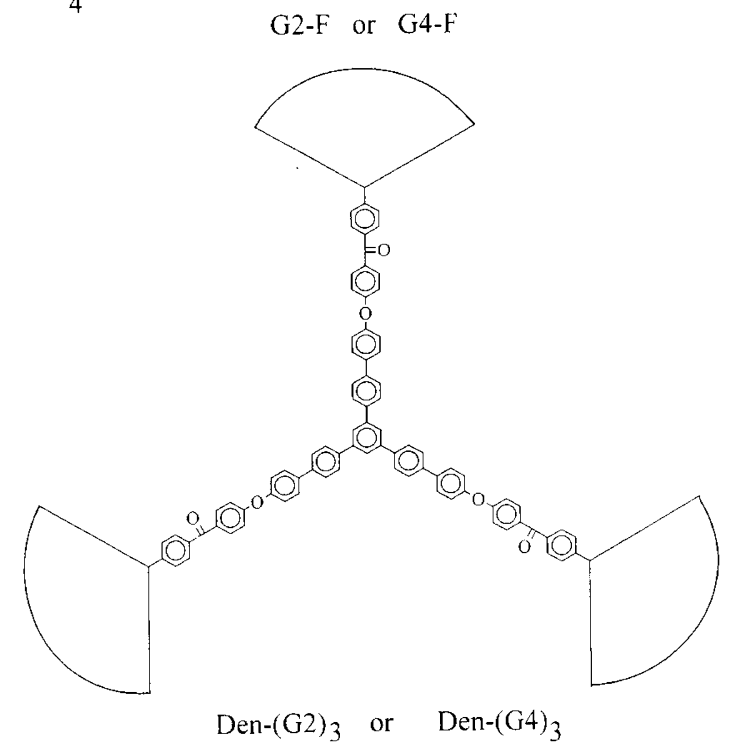

Scheme 3. cules were clearly as the expected structures.

The dendritic molecules were soluble in various organic solvents such as amide solvents, dimethyl sulfoxide, tetrahydrofuran, methylene chloride, chloroform and benzene as well as the poly(ether ether ketone) dendrimers with methoxy groups on the periphery, prepared using only 2 as the building block. ${ }^{14}$

Thermal behavior of these dendritic molecules was evaluated by differential scanning calorimetry (DSC), and appeared non-crystalline and only glass transition temperature $\left(T_{\mathrm{g}}\right)$ was observed. $T_{\mathrm{g}}$ s of the dendrons, $\mathbf{G 2}$ F, G3-OH, G3-Br, and $\mathbf{G 4}-\mathbf{F}$ were $58^{\circ} \mathrm{C}, 86^{\circ} \mathrm{C}, 84^{\circ} \mathrm{C}$, and $95^{\circ} \mathrm{C}$, respectively, and drastic increment of $T_{\mathrm{g}}$ between G2-F and G3-OH was seen. The $T_{\mathrm{g}}$ s of these dendrons were higher than dendrons, ${ }^{26}$ which had the same cyano groups at the periphery and prepared by using only 1 as the building block. The presence of benzophenone unit in the present dendritic molecules may affect the structure and $T_{\mathrm{g}} \mathrm{s}$. However, $T_{\mathrm{g}} \mathrm{s}$ of Den-(G2) 3 and Den-(G4) were 95 and $96^{\circ} \mathrm{C}$, respectively, and independent on the molecular size.

Thermal stability of the dendrimers was evaluated by thermogravimetry (TG) in air. Den-(G2) 3 and Den-(G $4_{3}$, initiated thermal decomposition at $330^{\circ} \mathrm{C}$, and temperatures at which weight losses of $5 \%$ were observed were $390^{\circ} \mathrm{C}$ and $408^{\circ} \mathrm{C}$, respectively.
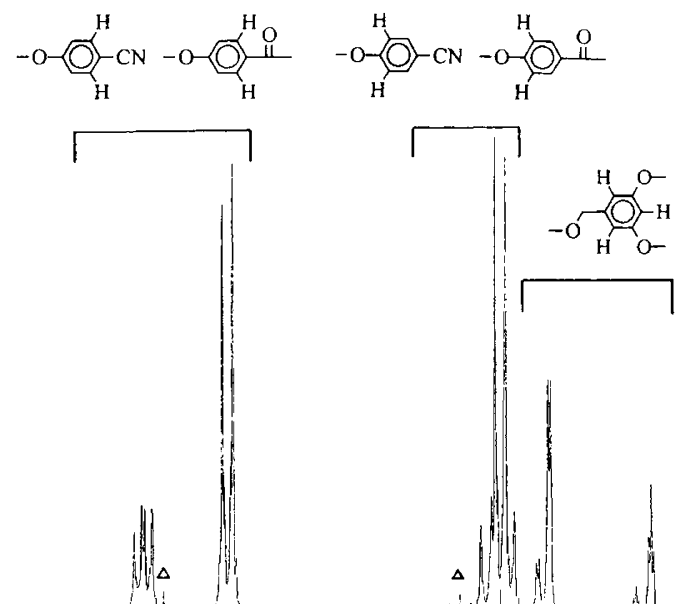

$\int_{-1}^{O-}$
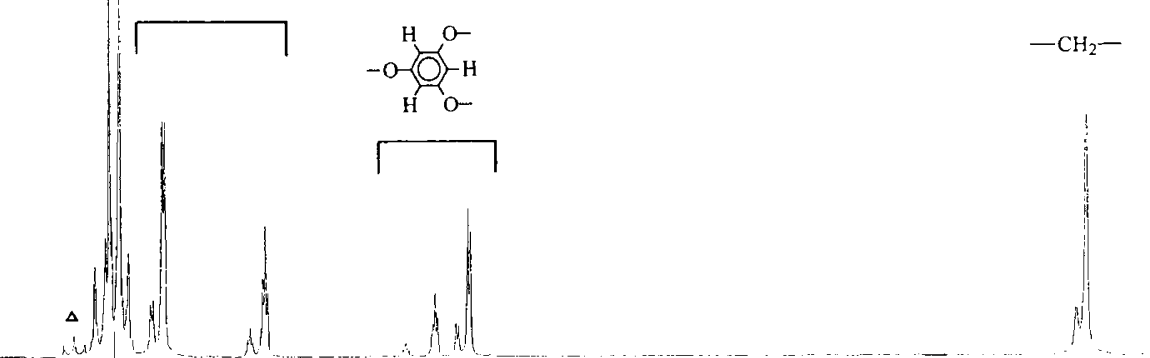

Den- $(\mathrm{G} 4)_{3}$

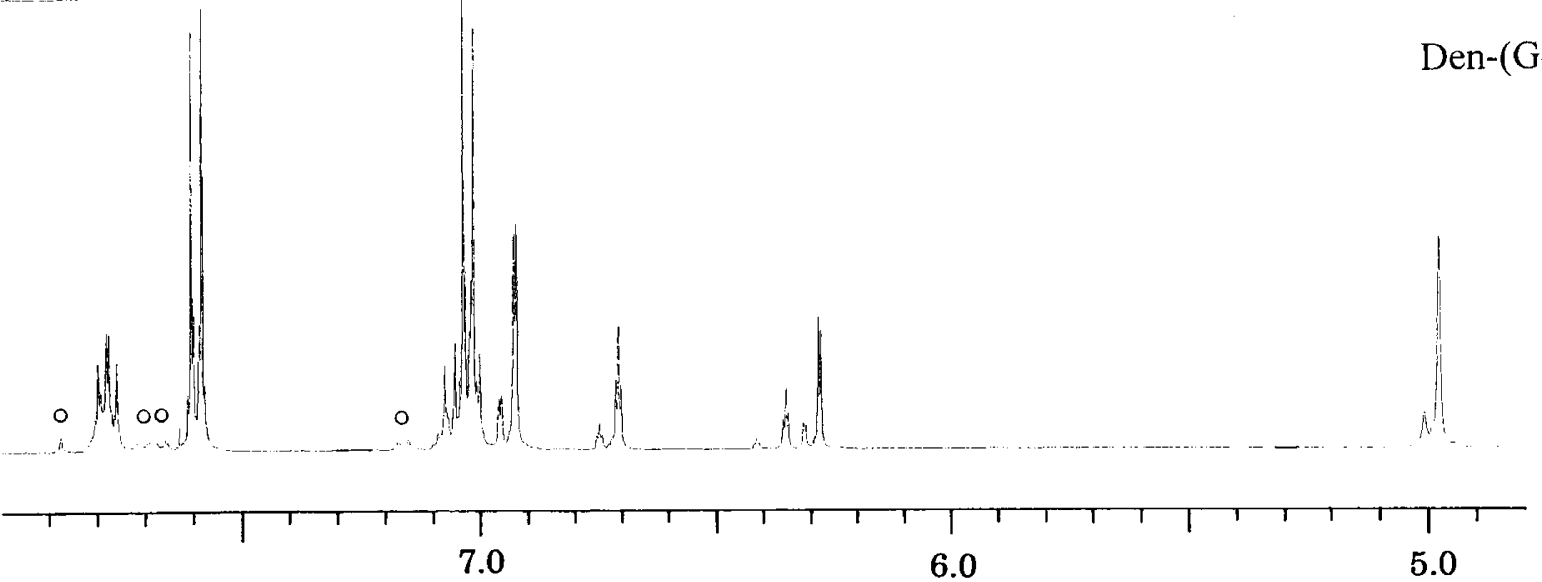

Figure 3. ${ }^{1} \mathrm{H}$ NMR spectra of G 4-F and Den-(G 4) ${ }_{3}$ at room temperature in $\mathrm{CDCl}_{3}$ 

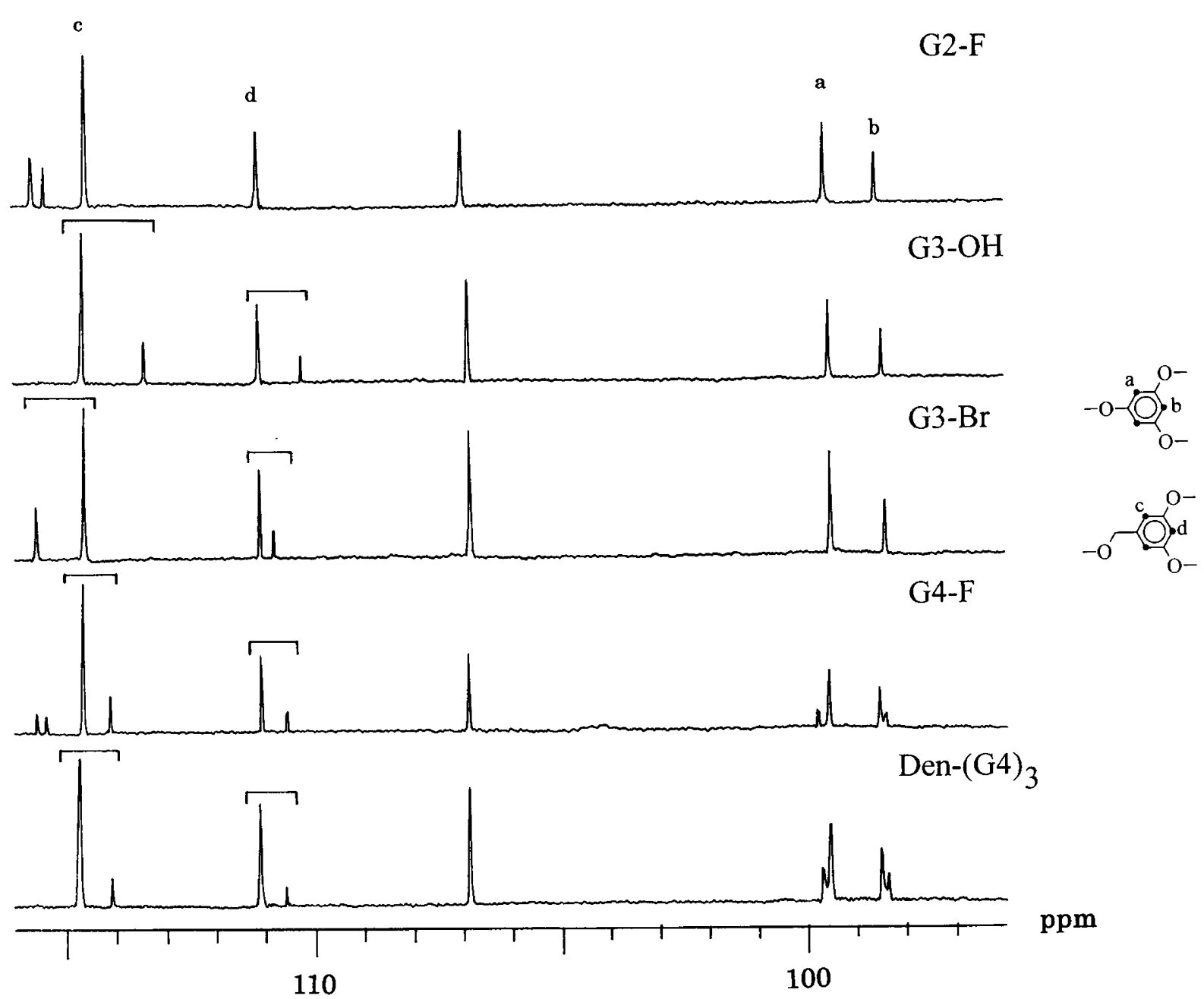

Figure 4. ${ }^{13} \mathrm{C}$ NMR spectra of G 2-F, G 3-OH, G 3-Br, G 4-F, and Den-(G 4) $)_{3}$ at room temperature in $\mathrm{CDCl}_{3}$.

\section{EXPERIMENTAL}

\section{Materials}

$p$-Fluorobenzonitrile was purified by distillation under reduced pressure, and triphenylphosphine was recrystallized from toluene. 3, 5-dihydroxybenzyl alcohol, 1, tetrabromomethane, and potassium carbonate were used as supplied. All solvents were purified by distillation before use.

\section{Measurements}

${ }^{1} \mathrm{H}$ and ${ }^{13} \mathrm{C}$ NMR spectra and IR spectra were recorded on a JNM-GSX-400 FT-NMR spectrometer and Shimadzu IR 435 spectro-photometer, respectively. The measurements of NMR were performed at room temperature using chloroform- $d_{1}$ as a solvent. GPC was performed using a Polymer Laboratories analytical column, PL gel $5 \mu$ MIXED-C, and tetrahydrofuran (THF) as eluent at $35^{\circ} \mathrm{C}$. DSC was performed with a Shimadzu DSC60 , and measurements were made at a heating rate of 10 ${ }^{\circ} \mathrm{C} \mathrm{min}^{-1}$ in nitrogen. TG was performed with Rigaku Thermal Analysis Station TG 8110, and the measurements were made at a heating rate of $10^{\circ} \mathrm{C} \mathrm{min}$ min $^{-1}$ in air. MALDI-TOF-MS spectra were recorded on a Shimadzu/ Kratos Kompact MALDI II equipped with a $337 \mathrm{~nm}$ ni- trogen laser. Sample preparation was as follows. A solution of the analyte $(5 \mathrm{mg})$, the matrix $(20 \mathrm{mg})$, and trifluoroacetic acid (one drop) in THF ( $1 \mathrm{~mL}$ ) was prepared and a $1 \mu \mathrm{l}$ of this matrix / sample solution was transferred to a stainless steel sample plate via automatic pipette. Measurement was performed in positive ion mode using 2,5-dihydroxybenzoic acid as the matrix.

\section{Synthesis}

3, 5-Dihydroxy-4'-(4-fluorobenzoyl) diphenylether, 2. 3,5-Dimethoxy-4' $-\left(4\right.$-fluorobenzoyl )diphenylether, ${ }^{14} \mathbf{3}$, $(10.57 \mathrm{~g}, 30 \mathrm{mmol})$ was heated together with pyridine hydrochloride $(50 \mathrm{~g})$ at reflux temperature $\left(240^{\circ} \mathrm{C}\right)$ for about $30 \mathrm{~min}$. After the reaction mixture was homogeneous, it was poured into water $(1000 \mathrm{~mL})$, and extracted twice with $100 \mathrm{~mL}$ of ethyl acetate. The combined extract was dried over anhydrous magnesium sulfate. After evaporation of the solvent, pure 2 was obtained by silica gel column eluted by methylene chloride and ethyl acetate $(2: 1) . \mathrm{Mp}: 137-138^{\circ} \mathrm{C}$. Yield : $8.8 \mathrm{~g}$ $(90 \%)$. IR (KBr) : $3400-3000,1640,1590,1500,1240$, $1160 \mathrm{~cm}^{-1} .{ }^{1} \mathrm{H} \mathrm{NMR}\left(\mathrm{CDCl}_{3}, \mathrm{ppm}\right): \delta 5.40(\mathrm{~s}, 2 \mathrm{H}), 6.15$ $(\mathrm{d}, 2 \mathrm{H}, J=2.2 \mathrm{~Hz}), 6.19(\mathrm{t}, 1 \mathrm{H}, d=2.2 \mathrm{~Hz}), 7.06(\mathrm{~d}, 2 \mathrm{H}, J$ $=8.8 \mathrm{~Hz}), 7.16(\mathrm{~m}, 2 \mathrm{H}), 7.77(\mathrm{~d}, 2 \mathrm{H}, J=8.8 \mathrm{~Hz}), 7.81(\mathrm{~m}$, $2 \mathrm{H}) .{ }^{13} \mathrm{C} \mathrm{NMR}\left(\mathrm{CDCl}_{3}, \mathrm{ppm}\right): \delta 99.28,99.88,115.53(\mathrm{~d}, J$ $=22.3 \mathrm{~Hz}), 117.92,132.09,132.31,132.55(\mathrm{~d}, J=9.5 \mathrm{~Hz})$, 
$133.89(\mathrm{~d}, J=3.2 \mathrm{~Hz}), 157.66,157.88,160.99,165.37(\mathrm{~d}, J$ $=234.3 \mathrm{~Hz}$ ), 194.61. Anal. Calcd for $\mathrm{C}_{19} \mathrm{H}_{13} \mathrm{FO}_{4}: \mathrm{C}$, 70.37; H, 4.04. Found : C, $70.43 ; \mathrm{H}, 4.09$.

1, 3, 5-Tris(p-(p-hydroxyphenyl)phenyl))benzene, 4.4 was prepared from $1,3,5$-tris $\left(p\right.$-bromophenyl)benzene. ${ }^{27}$ $1,3,5$-Tris ( $p$-bromophenyl)benzene $(5.43 \mathrm{~g}, 10 \mathrm{mmol})$, (4methoxyphenyl)boronic acid $(6.08 \mathrm{~g}, 40 \mathrm{mmol})$, potassium carbonate $(5.53 \mathrm{~g}, 40 \mathrm{mmol})$, and deoxygenated toluene $(100 \mathrm{~mL})$ were added to a flask equipped with a reflux condenser. The flask was flushed with nitrogen and tetrakis (triphenlyphosphine)paladium $\left(\mathrm{Pd}\left(\mathrm{PPh}_{3}\right)_{4}\right)$ $(0.2 \mathrm{~g})$ was added to the reaction mixture. After the mixture was stirred at $90^{\circ} \mathrm{C}$ for $8 \mathrm{~h}$, salts were removed by filtration, and the solvent was evaporated. The residue was recrystallized twice from toluene to give pure $1,3,5$ $\operatorname{tris}(p-(p$-methoxyphenyl $)$ phenyl $))$ benzene. Yield : $3.93 \mathrm{~g}$ (63\%). Mp : $201-202^{\circ} \mathrm{C}$. IR (KBr) : 2940, 1610, 1500, $1250 \mathrm{~cm}^{-1} .{ }^{1} \mathrm{H} \mathrm{NMR}\left(\mathrm{CDCl}_{3}, \mathrm{ppm}\right): \delta 3.85(\mathrm{~s}, 9 \mathrm{H}), 7.01$ $(\mathrm{d}, 6 \mathrm{H}, J=2.2 \mathrm{~Hz}), 7.59(\mathrm{~d}, 6 \mathrm{H}, J=8.8 \mathrm{~Hz}), 7.72(\mathrm{~d}, 6 \mathrm{H}, J$ $=8.8 \mathrm{~Hz}), 7.77(\mathrm{~d}, 6 \mathrm{H}, J=8.8 \mathrm{~Hz}), 7.86(\mathrm{~s}, 3 \mathrm{H}) .{ }^{13} \mathrm{C}$ NMR $\left(\mathrm{CDCl}_{3}, \mathrm{ppm}\right): \delta 114.44,124.85,127.17,127.71,128.12$, 133.35, 139.57, 140.18, 142.08, 159.49. Anal. Calcd for $\mathrm{C}_{45} \mathrm{H}_{36} \mathrm{O}_{3}$ : C, 86.51; H, 5.81. Found : C, $86.22 ; \mathrm{H}, 5.60$.

$1,3,5$-Tris $(p$-( $p$-methoxyphenyl)phenyl $))$ benzene $(3.12$ $\mathrm{g}, 5 \mathrm{mmol}$ ) was heated together with pyridine hydrochloride $(50 \mathrm{~g})$ at reflux temperature $\left(240^{\circ} \mathrm{C}\right)$ for about 30 min. After the reaction mixture was homogeneous, it was poured into water $(500 \mathrm{~mL})$, and extracted twice with $100 \mathrm{~mL}$ of ethyl acetate. The combined extracts was dried over anhydrous magnesium sulfate. After evaporation of the solvent, pure 4 was obtained by silica gel column eluted by methylene chloride and ethyl acetate (1: 1). Yield : $2.56 \mathrm{~g}(87 \%) . \mathrm{Mp}: 198-200^{\circ} \mathrm{C}$. IR (KBr) : $3400-3000,1590,1500,1300-1200 \mathrm{~cm}^{-1} .{ }^{1} \mathrm{H}$ NMR (dimethyl sulfoxide (DMSO)- $\left.d_{6}, \mathrm{ppm}\right): \delta 6.89(\mathrm{~d}, 6 \mathrm{H}, J=$ $2.2 \mathrm{~Hz}), 7.56(\mathrm{~d}, 6 \mathrm{H}, J=8.8 \mathrm{~Hz}), 7.72(\mathrm{~d}, 6 \mathrm{H}, J=8.8 \mathrm{~Hz})$, $7.92(\mathrm{~d}, 6 \mathrm{H}, J=8.8 \mathrm{~Hz}), 7.95(\mathrm{~s}, 3 \mathrm{H}), 9.87(\mathrm{~s}, 3 \mathrm{H}) .{ }^{13} \mathrm{C}$ NMR (DMSO- $\left.d_{6}, \mathrm{ppm}\right): \delta 116.61,124.56,127.17,128.28$, $128.44,131.20,138.86,140.37,142.06,158.08$. Anal. Calcd for $\mathrm{C}_{42} \mathrm{H}_{30} \mathrm{O}_{3}$ : C, 86.57; H, 5.19. Found: C, $86.52 ; \mathrm{H}, 4.99$.

General Procedure for the Synthesis of $\boldsymbol{G}-\boldsymbol{O H}$. In a flask, a mixture of 1 (1.00 equiv), $p$-fluorobenzonitrile ( 2.00 equiv), potassium carbonate (1.00 equiv), toluene, and $N, N$-dimethylacetamide was stirred at $130^{\circ} \mathrm{C}$ for $1 \mathrm{~h}$. The temperature was raised to $150^{\circ} \mathrm{C}$ and water formed during the reaction was removed as an azeotrope with toluene. The reaction mixture was stirred at this temperature for $1.5 \mathrm{~h}$. After the reaction was complete, the mixture was cooled to about $80^{\circ} \mathrm{C}$, and the solvent was evaporated under a reduced pressure of $15-20$ torr. The residue was washed with $300 \mathrm{~mL}$ of water and extracted twice with $200 \mathrm{~mL}$ of methylene chloride. After the combined extract was dried over anhydrous magnesium sulfate, the solvent was evaporated. The crude product was purified as outlined in the following.

General Procedure for the Synthesis of $\boldsymbol{G}-\boldsymbol{B r}$. In a flask, a mixture of G-OH (1.00 equiv), carbon tetrabromide ( 1.25 equiv), triphenylphosphine ( 1.25 equiv), and dry tetrahydrofuran was stirred under nitrogen at room temperature for $1 \mathrm{~h}$. The reaction mixture was poured into water and extracted twice with $100 \mathrm{~mL}$ of methylene chloride. After the combined extract was dried over anhydrous magnesium sulfate, the solvent was evaporated. The crude product was purified as outlined in the following.

General Procedure for the Synthesis of $\boldsymbol{G}-\boldsymbol{F}$. A mixture of $\mathbf{G}-\mathbf{B r}$ (2.00 equiv), 2 (1.00 equiv), potassium carbonate (2.00 equiv), and a few drop of 18-crown- 6 in acetone was heated at reflux and stirred vigorously under nitrogen for $24 \mathrm{~h}$. The reaction mixture was poured into water and extracted twice with $100 \mathrm{~mL}$ of methylene chloride. After the combined extract was dried over anhydrous magnesium sulfate, the solvent was evaporated. The crude product was purified as outlined in the following.

General Procedure for the Synthesis of Den-(G) ${ }_{3}$. In a flask, a mixture of $\mathbf{G}-\mathbf{F}$ (3.33 equiv), 4 (1.00 equiv), potassium carbonate (1.00 equiv), toluene, and $N, N$ dimethylacetamide was stirred at $130^{\circ} \mathrm{C}$ for $1 \mathrm{~h}$. The temperature was raised to $150^{\circ} \mathrm{C}$ and water formed during the reaction was removed as an azeotrope with toluene. The reaction mixture was stirred at this temperature for $1.5 \mathrm{~h}$. After the reaction was complete, the mixture was cooled to about $80^{\circ} \mathrm{C}$, and the solvent was evaporated under reduced pressure of $15-20$ torr. The residue was washed with $300 \mathrm{~mL}$ of water and extracted twice with $200 \mathrm{~mL}$ of methylene chloride. After the combined extract was dried over anhydrous magnesium sulfate, the solvent was evaporated. The crude product was purified as outlined in the following text.

G1-OH. This compound was prepared from $p$ fluorobenzonitrile and $\mathbf{1}$, and purified by silica gel column chromatography eluted by methylene chloride and ethyl acetate $(15: 1)$. Yield : $11.98 \mathrm{~g}(70 \%)$. Mp : 103 $104^{\circ} \mathrm{C}$. IR (KBr) : $3400-3000,2940,2230,1600,1500$, $1230 \mathrm{~cm}^{-1}$. ${ }^{1} \mathrm{H}$ NMR $\left(\mathrm{CDCl}_{3}, \mathrm{ppm}\right): \delta 1.95(\mathrm{t}, 1 \mathrm{H}, J=5.5$ $\mathrm{Hz}), 4.72(\mathrm{~d}, 2 \mathrm{H}, J=5.5 \mathrm{~Hz}), 6.70(\mathrm{t}, 1 \mathrm{H}, J=2.2 \mathrm{~Hz}), 6.94$ $(\mathrm{d}, 2 \mathrm{H}, J=2.2 \mathrm{~Hz}), 7.07(\mathrm{~d}, 4 \mathrm{H}, J=8.8 \mathrm{~Hz}), 7.64(\mathrm{~d}, 4 \mathrm{H}, J$ $=8.8 \mathrm{~Hz}) .{ }^{13} \mathrm{C} \mathrm{NMR}\left(\mathrm{CDCl}_{3}, \mathrm{ppm}\right): \delta 64.07,106.73$, $110.77,114.13,118.49,118.52,134.27,145.43,156.66$, 160.64. Anal. Calcd for $\mathrm{C}_{21} \mathrm{H}_{14} \mathrm{~N}_{2} \mathrm{O}_{3}$ : C, 73.68; H, 4.12. Found : C, $73.43 ; \mathrm{H}, 4.06$.

$\boldsymbol{G 1}-\boldsymbol{B r}$. This compound was prepared from $\mathbf{G} \mathbf{1}-\mathbf{O H}$, and purified by silica gel column chromatography eluted by methylene chloride, and pure $\mathbf{G} \mathbf{1}-\mathbf{B r}$ was obtained by recrystallization from toluene. Yield : $11.55 \mathrm{~g} \mathrm{(95 \% ).}$ $\mathrm{Mp}: 160-161^{\circ} \mathrm{C}$. IR (KBr): 2940, 2230, 1600, 1500, $1230 \mathrm{~cm}^{-1} .{ }^{1} \mathrm{H} \mathrm{NMR}\left(\mathrm{CDCl}_{3}, \mathrm{ppm}\right): \delta 4.41(\mathrm{~s}, 2 \mathrm{H}), 6.70$ $(\mathrm{t}, 1 \mathrm{H}, J=2.2 \mathrm{~Hz}), 6.93(\mathrm{~d}, 2 \mathrm{H}, J=2.2 \mathrm{~Hz}), 7.07(\mathrm{~d}, 4 \mathrm{H}, J$ $=8.8 \mathrm{~Hz}), 7.66(\mathrm{~d}, 4 \mathrm{H}, J=8.8 \mathrm{~Hz}) .{ }^{13} \mathrm{C} \mathrm{NMR}\left(\mathrm{CDCl}_{3}\right.$, $\mathrm{ppm}): \delta 31.53,107.12,111.41,116.43,118.43,118.68$, 134.35, 141.84, 156.75, 160.23. Anal. Calcd for $\mathrm{C}_{21} \mathrm{H}_{13}$ $\mathrm{BrN}_{2} \mathrm{O}_{2}$ : C, 62.24; H, 3.23. Found : C, 62.18; H, 3.27.

G2-F. This compound was prepared from $\mathbf{G} \mathbf{1}-\mathbf{B r}$, and purified by silica gel column eluted by methylene chloride and ethyl acetate $(30: 1)$. Yield : $11.19 \mathrm{~g}(92 \%)$. IR (KBr) : 2940, 2230,1650,1590, 1500, $1230 \mathrm{~cm}^{-1} \cdot{ }^{1} \mathrm{H}$ NMR $\left(\mathrm{CDCl}_{3}, \mathrm{ppm}\right): \delta 4.99(\mathrm{~s}, 4 \mathrm{H}), 6.30(\mathrm{~d}, 2 \mathrm{H}, J=2.2$ $\mathrm{Hz}), 6.37(\mathrm{t}, 1 \mathrm{H}, J=2.2 \mathrm{~Hz}), 6.72(\mathrm{t}, 2 \mathrm{H}, J=2.2 \mathrm{~Hz}), 6.94$ (d, $4 \mathrm{H}, J=2.2 \mathrm{~Hz}), 7.05(\mathrm{~m}, 10 \mathrm{H}), 7.17(\mathrm{~m}, 2 \mathrm{H}), 7.62(\mathrm{~d}, 8$ $\mathrm{H}, J=8.8 \mathrm{~Hz}), 7.79(\mathrm{~d}, 2 \mathrm{H}, J=8.8 \mathrm{~Hz}), 7.82(\mathrm{~m}, 2 \mathrm{H}) .{ }^{13} \mathrm{C}$ NMR $\left(\mathrm{CDCl}_{3}, \mathrm{ppm}\right): \delta 69.06,98.58,99.64,106.99$, $111.19,114.65,115.50(\mathrm{~d}, J=22.3 \mathrm{~Hz}), 117.73,118.43$, $118.58,132.26,132.42$ (d, $J=9.5), 132.47,133.83$ (d, $J=$ $3.2 \mathrm{~Hz}$ ), 134.30, 140.77, 156.83, 157.69, 160.28, 160.37, 
160.61, $165.31(\mathrm{~d}, J=254.3 \mathrm{~Hz}), 193.88$. Anal. Calcd for $\mathrm{C}_{61} \mathrm{H}_{37} \mathrm{FN}_{4} \mathrm{O}_{8}$ : C, 75.30; H, 3.83. Found : C, 75.20; H, 3.71 .

G3-OH. This compound was prepared from G2-F, and purified by silica gel column chromatography beginning with methylene chloride and ethyl acetate $(25: 1)$ as eluent and gradually changing to methylene chloride and ethyl acetate $(10: 1)$. Yield : $7.32 \mathrm{~g}(65 \%)$. IR (KBr) : $3400-3000,2940,2230,1650,1590,1500,1230 \mathrm{~cm}^{-1}$. ${ }^{1} \mathrm{H} \mathrm{NMR}\left(\mathrm{CDCl}_{3}, \mathrm{ppm}\right): \delta 4.71(\mathrm{~s}, 2 \mathrm{H}), 5.00(\mathrm{~s}, 8 \mathrm{H}), 6.29$ $(\mathrm{d}, 4 \mathrm{H}, J=2.2 \mathrm{~Hz}), 6.37(\mathrm{t}, 2 \mathrm{H}, J=2.2 \mathrm{~Hz}), 6.72(\mathrm{t}, 4 \mathrm{H}, J$ $=2.2 \mathrm{~Hz}), 6.74(\mathrm{t}, 4 \mathrm{H}, J=2.2 \mathrm{~Hz}), 6.93(\mathrm{~d}, 2 \mathrm{H}, J=2.2 \mathrm{~Hz})$, $6.94(\mathrm{~d}, 8 \mathrm{H}, J=2.2 \mathrm{~Hz}), 7.02-7.07(\mathrm{~m}, 20 \mathrm{H}), 7.08(\mathrm{~d}, 4 \mathrm{H}$, $J=8.8 \mathrm{~Hz}), 7.62(\mathrm{~d}, 16 \mathrm{H}, J=8.8 \mathrm{~Hz}), 7.75-7.83(\mathrm{~m}, 8 \mathrm{H})$. ${ }^{13} \mathrm{C} \mathrm{NMR}\left(\mathrm{CDCl}_{3}, \mathrm{ppm}\right): \delta 64.24,69.02,98.50,99.55$, $106.90,110.25,111.22,113.45,114.65,117.73,117.79$, $118.46,118.55,132.21,132.28,132.58,132.72,134.30$, $140.75,144.32,156.79,157.28,157.72,160.23,160.37$, 160.38, 160.60, 194.07. Anal. Calcd for $\mathrm{C}_{129} \mathrm{H}_{80} \mathrm{~N}_{8} \mathrm{O}_{19}$ : C, 75.73; H, 3.94. Found : C, $75.52 ; \mathrm{H}, 3.88$.

G3-Br. This compound was prepared from G3-OH, and purified by silica gel column chromatography beginning with methylene chloride and ethyl acetate $(40: 1)$ as eluent and gradually changing to methylene chloride and ethyl acetate $(20: 1)$. Yield : $6.14 \mathrm{~g}(91 \%)$. IR (KBr) : $2940,2230,1650,1590,1500,1230 \mathrm{~cm}^{-1} .{ }^{1} \mathrm{H} \mathrm{NMR}$ $\left(\mathrm{CDCl}_{3}, \mathrm{ppm}\right): \delta 4.43(\mathrm{~s}, 2 \mathrm{H}), 5.00(\mathrm{~s}, 8 \mathrm{H}), 6.30(\mathrm{~d}, 4 \mathrm{H}, J$ $=2.2 \mathrm{~Hz}), 6.36(\mathrm{t}, 2 \mathrm{H}, J=2.2 \mathrm{~Hz}), 6.73(\mathrm{t}, 4 \mathrm{H}, J=2.2 \mathrm{~Hz})$, $6.75(\mathrm{t}, 4 \mathrm{H}, J=2.2 \mathrm{~Hz}), 6.93(\mathrm{~d}, 2 \mathrm{H}, J=2.2 \mathrm{~Hz}), 6.94(\mathrm{~d}, 8$ $\mathrm{H}, J=2.2 \mathrm{~Hz}), 7.02-7.07(\mathrm{~m}, 20 \mathrm{H}), 7.10(\mathrm{~d}, 4 \mathrm{H}, J=8.8$ $\mathrm{Hz}), 7.62(\mathrm{~d}, 16 \mathrm{H}, J=8.8 \mathrm{~Hz}), 7.81(\mathrm{~d}, 4 \mathrm{H}, J=8.8 \mathrm{~Hz})$, $7.83(\mathrm{~d}, 4 \mathrm{H}, J=8.8 \mathrm{~Hz}) \cdot{ }^{13} \mathrm{C} \mathrm{NMR}\left(\mathrm{CDCl}_{3}, \mathrm{ppm}\right): \delta 31.99$ $69.00,98.46,99.53,106.88,110.82,111.20,114.65$, $115.66,117.72,117.98,118.44,118.54,132.23,132.31$, $132.63,132.86,134.29,140.74,141.35,156.77,157.35$, $157.69,160.14,160.22,160.36,160.45,194.02$. Anal. Calcd for $\mathrm{C}_{129} \mathrm{H}_{79} \mathrm{BrN}_{8} \mathrm{O}_{18}$ : C, 73.47; H, 3.78. Found: C, 73.29 ; H, 3.80 .

G4-F. This compound was prepared from G3-Br, and purified by silica gel column chromatography beginning with methylene chloride and ethyl acetate $(40: 1)$ as eluent and gradually changing to methylene chloride and ethyl acetate $(15: 1)$. Yield : $4.82 \mathrm{~g}(88 \%)$. IR (KBr) : $2940,2230,1650,1590,1500,1230 \mathrm{~cm}^{-1} .{ }^{1} \mathrm{H}$ NMR $\left(\mathrm{CDCl}_{3}, \mathrm{ppm}\right): \delta 4.98(\mathrm{~s}, 16 \mathrm{H}), 5.01(\mathrm{~s}, 4 \mathrm{H}), 6.28(\mathrm{~d}, 8 \mathrm{H}, J$ $=2.2 \mathrm{~Hz}), 6.31(\mathrm{~d}, 2 \mathrm{H}, J=2.2 \mathrm{~Hz}), 6.37(\mathrm{t}, 4 \mathrm{H}, J=2.2 \mathrm{~Hz})$ $6.42(\mathrm{t}, 1 \mathrm{H}, J=2.2 \mathrm{~Hz}), 6.72(\mathrm{t}, 8 \mathrm{H}, J=2.2 \mathrm{~Hz}), 6.75(\mathrm{t}, 2$ $\mathrm{H}, J=2.2 \mathrm{~Hz}), 6.94(\mathrm{~d}, 16 \mathrm{H}, J=2.2 \mathrm{~Hz}), 6.96(\mathrm{~d}, 4 \mathrm{H}, J=$ $2.2 \mathrm{~Hz}), 7.00-7.08(\mathrm{~m}, 50 \mathrm{H}), 7.12(\mathrm{~m}, 2 \mathrm{H}), 7.61(\mathrm{~d}, 32 \mathrm{H}, J$ $=8.8 \mathrm{~Hz}), 7.75-7.83(\mathrm{~m}, 20 \mathrm{H}),{ }^{13} \mathrm{C} \mathrm{NMR}\left(\mathrm{CDCl}_{3}, \mathrm{ppm}\right)$ : $\delta 69.07,69.30,98.51,98.54,99.61,99.77,106.93,110.57$, $111.23,114.10,114.70,115.46(\mathrm{~d}, J=22.3 \mathrm{~Hz}), 117.69$, $117.76,117.88,118.48,118.59,132.25,132.31,132.33$, $132.41(\mathrm{~d}, J=9.5 \mathrm{~Hz}), 132.47,132.66,132.80,133.92(\mathrm{~d}$, $J=3.2 \mathrm{~Hz}), 134.32,140.44,140.79,156.82,157.44$, $157.53,157.72,160.28,160.36,160.41,160.42,160.50$, 160.80, 165.22 (d, $J=254.3 \mathrm{~Hz}), 193.90,194.01$. Anal. Calcd for $\mathrm{C}_{277} \mathrm{H}_{169} \mathrm{FN}_{16} \mathrm{O}_{40}$ : C, 75.95; H, 3.89. Found : C, $75.87 ; \mathrm{H}, 3.87$.

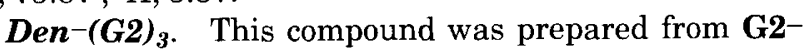
F, and purified by silica gel column chromatography beginning with methylene chloride and ethyl acetate (40: 1 ) as eluent and gradually changing to methylene chlo- ride and ethyl acetate $(20: 1)$. Yield : $4.23 \mathrm{~g}(82 \%)$. IR $(\mathrm{KBr}): 2940,2230,1650,1590,1500,1230 \mathrm{~cm}^{-1} \cdot{ }^{1} \mathrm{H}$ $\mathrm{NMR}\left(\mathrm{CDCl}_{3}, \mathrm{ppm}\right): \delta 4.99(\mathrm{~s}, 12 \mathrm{H}), 6.28(\mathrm{~d}, 6 \mathrm{H}, J=2.2$ $\mathrm{Hz}), 6.36(\mathrm{t}, 3 \mathrm{H}, J=2.2 \mathrm{~Hz}), 6.72(\mathrm{t}, 6 \mathrm{H}, J=2.2 \mathrm{~Hz}), 6.93$ $(\mathrm{d}, 12 \mathrm{H}, J=2.2 \mathrm{~Hz}), 7.05(\mathrm{~m}, 30 \mathrm{H}), 7.12(\mathrm{~d}, 6 \mathrm{H}, J=8.8$ $\mathrm{Hz}), 7.22(\mathrm{~d}, 6 \mathrm{H}, J=8.8 \mathrm{~Hz}), 7.62(\mathrm{~d}, 24 \mathrm{H}, J=8.8 \mathrm{~Hz})$, $7.72(\mathrm{~d}, 6 \mathrm{H}, J=8.8 \mathrm{~Hz}), 7.76(\mathrm{~d}, 6 \mathrm{H}, J=8.8 \mathrm{~Hz}), 7.80-$ $7.87(\mathrm{~m}, 18 \mathrm{H}) .7 .91(\mathrm{~s}, 3 \mathrm{H}) .{ }^{13} \mathrm{C} \mathrm{NMR}\left(\mathrm{CDCl}_{3}, \mathrm{ppm}\right): \delta$ $69.05,98.49,99.50,106.96,111.20,114.66,117.40$, $117.78,118.46,118.57,120.42,125.02,127.44,127.82$, $128.66,132.12,132.21,132.31,132.96,134.32,137.04$, $139.55,139.98,140.77,141.92,155.22,156.82,157.83$, $160.25,160.31,160.37,161.42,194.13$. Anal. Calcd for $\mathrm{C}_{225} \mathrm{H}_{138} \mathrm{~N}_{12} \mathrm{O}_{27}$ : C, 78.52; H, 4.04. Found: C, 78.56 ; $\mathrm{H}, 4.01$.

Den-(G4) $)_{3}$. This compound was prepared from $\mathbf{G 4}-\mathbf{F}$, and purified by the same by silica gel column chromatography beginning with methylene chloride and ethyl acetate $(30: 1)$ as eluent and gradually changing to methylene chloride and ethyl acetate $(15: 1)$. Yield: $4.61 \mathrm{~g}$ $(75 \%)$. IR (KBr) : 2940, 2230, 1650, 1590, 1500, 1230 $\mathrm{cm}^{-1} \cdot{ }^{1} \mathrm{H} \mathrm{NMR}\left(\mathrm{CDCl}_{3}, \mathrm{ppm}\right): \delta 4.98(\mathrm{~s}, 48 \mathrm{H}), 5.02(\mathrm{~s}, 12$ $\mathrm{H}), 6.28(\mathrm{~d}, 24 \mathrm{H}, J=2.2 \mathrm{~Hz}), 6.32(\mathrm{~d}, 6 \mathrm{H}, J=2.2 \mathrm{~Hz}), 6.36$ $(\mathrm{t}, 12 \mathrm{H}, J=2.2 \mathrm{~Hz}), 6.42(\mathrm{t}, 3 \mathrm{H}, J=2.2 \mathrm{~Hz}), 6.72(\mathrm{t}, 24 \mathrm{H}$, $J=2.2 \mathrm{~Hz}), 6.75(\mathrm{t}, 6 \mathrm{H}, J=2.2 \mathrm{~Hz}), 6.93(\mathrm{~d}, 48 \mathrm{H}, J=2.2$ $\mathrm{Hz}), 6.97(\mathrm{~d}, 12 \mathrm{H}, J=2.2 \mathrm{~Hz}), 7.00-7.10(\mathrm{~m}, 156 \mathrm{H}), 7.17$ $(\mathrm{d}, 6 \mathrm{H}, J=8.8 \mathrm{~Hz}), 7.61(\mathrm{~d}, 96 \mathrm{H}, J=8.8 \mathrm{~Hz}), 7.67(\mathrm{~d}, 6 \mathrm{H}$, $J=8.8 \mathrm{~Hz}), 7.71(\mathrm{~d}, 6 \mathrm{H}, J=8.8 \mathrm{~Hz}), 7.75-7.83(\mathrm{~m}, 66 \mathrm{H})$. $7.88(\mathrm{~s}, 3 \mathrm{H}) .{ }^{13} \mathrm{C} \mathrm{NMR}\left(\mathrm{CDCl}_{3}, \mathrm{ppm}\right): \delta 69.05,69.29$, 98.44, 98.52, 99.60, 99.68, 106.90, 110.57, 111.23, 114.11, $114.70,117.40,117.75,117.84,117.86,118.49,118.57$, $120.36,124.94,127.43,127.79,128.63,132.22,132.25$, $132.31,132.36,132.64,132.67,132.79,132.80,134.32$, $136.88,139.51,139.89,140.45,140.79,141.88,155.25$, $156.80,157.42,157.66,157.70,160.27,160.36,160.39$, 160.49, 160.53, 160.54, 161.21, 194.01, 194.10. Anal. Calcd for $\mathrm{C}_{873} \mathrm{H}_{534} \mathrm{~N}_{48} \mathrm{O}_{123}$ : C, $76.74 ; \mathrm{H}, 3.94$. Found : C, $76.58 ; \mathrm{H}, 3.81$.

Acknowledgment. The authors thank Prof. Hiroshi Mase and Mr. Toshio Tanabe of Ibaraki University for equipment and assistance in measuring MALDI-TOFMS spectra.

\section{REFERENCES AND NOTES}

1. D. A. Tomalia, A. M. Naylor, and W. A. Goddard, Angew. Chem., Int. Ed. Engl., 29, 138 (1990).

2. D. A. Tomalia and H. D. Durst, Top. Curr. Chem., 165, 193 (1993).

3. D. A. Tomalia and H. D. Durst, in "Supramolecular Chemistry I-Directed Synthesis Molecular Recognition", E. Weber, Ed., Topics in Current Chemistry Vol. 165, Springer-Verlag, Berlin, Heiderberg, 1993, pp 193-313.

4. G. R. Newkome, "Advances in Dendritic Macromolecules", JAI Press, Greenwich, CT, 1993. Y. H. Kim, Adv. Mater., 4, 764 (1992)

5. D. A. Tomalia, H. Baker, J. Dewald, M. Hall, G. Kallos, S. Martin, J. Ryder, and P. Smith, Polym. J., 17, 117 (1985).

6. D. A. Tomalia, H. Baker, J. Dewald, M. Hall, G. Kallos, S. Martin, J. Roeck, J. Ryder, and P. Smith, Macromolecules, 19, 2466 (1986).

7. D. A. Tomalia, M. Hall, and D. M. Hedstrand, J. Am. Chem. Soc., 109, 1601 (1987).

8. D. A. Tomalia, V. Berry, M. Hall, and D. M. Hedstrand, Macromolecules, $\mathbf{2 0}, 1164$ (1987). 
9. C. J. Hawker and J. M. J. Frechet. J. Chem. Soc., Chem. Commun., 1010 (1990).

10. C. J. Hawker and J. M. J. Frechet, J. Am. Chem. Soc., 112, 7638 (1990).

11. C. J. Hawker and J. M. J. Frechet, Macromolecules, 23, 4726 (1990).

12. E. C. Constable and A. M. W. C. Thompson, J. Chem. Soc., Chem. Commun., 617 (1992).

13. T. Nagasaki, S. Arimori, and S. Shinkai, J. Chem. Soc., Chem. Commun., 608 (1992).

14. A. Morikawa and K. Ono, Polym. J., 32, 234 (2000).

15. T. H. Mourey, S. R. Turner, M. Rubinstein, J. M. J. Frechet, C. J. Hawker, and K. L. Wooley, Macromolecules, 25, 2401 (1992).

16. G. R. Newkome, Z. Yao, G. R. Baker, and V. K. Gupta, J. Org. Chem., 50, 2003 (1985).

17. R. Spindler and J. M. J. Frechet. J. Chem. Soc., Perkin Trans., 1, 913 (1993).

18. L. J. Twyman, A. E. Beezer, and J. C. Mitchell, J. Chem. Soc.,
Perkin Trans., 1, 407 (1994).

19. Z. Xu, M. Kahr, K. L Walker, C. L. Wilkins, and J. S. Moore, J. Am. Chem. Soc., 116, 4537 (1994).

20. F. Zeng and S. C. Zimmerman, J. Am. Chem. Soc., 118, 5326 (1996).

21. S. K. Deb, T. M. Maddux, and L. Yu, J. Am. Chem. Soc., 119, 9079 (1997).

22. A. Morikawa and K. Ono, Macromolecules, 32, 1062 (1999).

23. G. R. Newkome, L. A. Godinez, and C. N. Moorefield, J. Chem. Soc., Chem. Commun., 1821 (1998).

24. G. R. Newkome, C. D. Weis, C. N. Moorefield, G. R. Baker, B. J. Childs, and J. Epperson, Angew. Chem., Int. Ed. Engl., 37, 307 (1998).

25. K. R. Gopidas, A. R. Leheny, G. Gaminati, N. J. Turro, and D. A. Tomalia, J. Am. Chem. Soc., 113, 7335 (1991).

26. K. L. Wooley, C. J. Hawker, J. M. Pochan, and J. M. J. Frechet. Macromolecules, 26, 1514 (1993)

27. Y.H. Kim and R. Beckerbauer, Macromolecules, 27, 1968 (1994). 